\title{
Condition and Feeding of American Plaice (Hippoglossoides platessoides) in the North Atlantic with Emphasis on the Flemish Cap
}

\author{
Concepción González, Esther Román and Xabier Paz \\ Centro Oceanográfico de Vigo (I. E. O.) \\ P. O. Box 1552, 36280 Vigo, Spain
}

\begin{abstract}
González, C., E. Román, and X. Paz. 2006. Condition and feeding of American plaice (Hippoglossoides platessodies) in the North Atlantic with emphasis on the Flemish Cap. J. Northw. Atl. Fish. Sci., 37: 87-102. doi:10.2960/J.v37.m556
\end{abstract}

\begin{abstract}
The seasonal, annual and geographical changes in the Relative Condition Factor $\left(K_{r}\right)$ of a total of 24410 individual American plaice (Hippoglossoides platessoides Fabricius) were analysed. These samples were collected in three areas of the North Atlantic (NAFO Division 3M and Div. 3LNO, and ICES Div. IIb) in commercial fishing and scientific surveys from 1992 to 2003. Condition presented significant variation in both sexes as far as area, season and year effects were concerned.

Condition decreased greatly in Div. 3M, slightly increased in Div. IIb and it was quite constant in Div. 3LNO in the considered period for each area. Relative Condition Factor value showed a remarkable relation with the estimated biomass in Div. 3M. Females showed a better condition than males, and condition in the periods of spring and summer was lower than in the periods of autumn and winter for both sexes. Interannual variation in condition was more evident in small sized (immature) individuals.
\end{abstract}

The spawning period corresponded with the peak of condition in females and with a decrease in males. Feeding intensity and condition were inversely related across season, however when the same period was studied across years they showed a similar pattern.

Food and feeding of 8543 individual American plaice from these three areas were examined. Feeding intensity was higher on the Flemish Cap (78\%). The main prey in the composition of stomach contents for this area, were Ophiuroidea (56\%), Hyperiidea (13\%) and Pandalus borealis (8\%). Changes in the main components of the diet were found in the last years. Feeding habits by size range and comparison with the other areas were also analysed.

Key words: American plaice, condition factor, Hippoglossoides platessoides, Flemish Cap, North Atlantic

\section{Introduction}

American plaice (Hippoglossoides platessoides Fabricius) is an economically and ecologically important flatfish that inhabits both sides of the North Atlantic. The American plaice stock in the Flemish Cap (NAFO Div. 3M) has recorded a steady decline since 1988. The 1984, 1986 and 1990 year-classes (ages 18, 16 and 12 in 2002) were the most abundant cohorts in the period, but good recruitment has not been observed since then. In fact, since the EU Survey on the Flemish Cap began in 1988, the American plaice estimated biomass showed a continuous fall from 11.9 tons in 1988 to 1.2 tons in 2000; from this year to 2003 it has shown a minimal annual recovery, but remains at very low levels (Saborido and Vázquez, MS 2003; Alpoim and Ávila, MS 2004; Casas, MS 2004). The biomass and SSB in Div. $3 \mathrm{~L}, 3 \mathrm{~N}$ and $3 \mathrm{O}$ were very low compared with historical levels.
SSB declined to the lowest observed level in 1994 and 1995. It has increased since then but still remains very low (Anon., 2004).

Simple condition indices provide a useful assessment of the physiological well-being of fishes and provide an indirect means of evaluating ecological relations and the effects of various management strategies (Murphy et al., 1991). Several studies have demonstrated that these indices are a measure of the energy reserves of fishes and their relationship with the environmental, maturity, feeding or parasitic conditions (Costopoulos and Fonds, 1989).

Other studies mention the possible relationship between a continuous deficit condition throughout the years and the current situation of a stock. The implications of a poor condition in the current biomass and in the situation 
of the stock have been studied in Atlantic cod (Gadus morhua), and an increase in the natural mortality has been observed. This fact contributed to lower production (Lambert and Dutil, 1997; Dutil and Lambert, 2000); and the decrease of the reproductive investment could affect the reproductive potential (fecundity and total eggs) and possible recruitment (Lambert and Dutil, 2000).

The temporal condition variations (seasonal and annual) of American plaice in three areas of North Atlantic - NAFO Div. 3M and 3LNO, and Svalbard Area, ICES Div. IIb - were examined in this study. Sex, maturity, and length were also considered in the period 1992-2003.

A study of the feeding of this species in these areas in the period 1993-2003 was also presented in order to analyse their possible relationship with the condition.

The aim of this study was to examine and to compare the condition stage of the individuals of three populations in the North Atlantic, and its relationship with the feeding habits and maturity cycle. The changes throughout the period 1992-2003 and the possible influence on the state of the population were also examined.

\section{Material and Methods}

A total of 24410 individual American plaice from the Northwest Atlantic and Arctic were analysed from research and commercial surveys during the period 1992-2003 (Tables 1 and 2). The surveys were the following: the EU Survey in "Flemish Cap" Div. 3M (Casas, MS 2004), "Platuxa" Spanish Survey in NAFO Div. 3NO (González Troncoso et al., MS 2004), "Fletán Negro-3L" Spanish Survey (X. Paz, Centro Oceanográfico de Vigo (I.E.O.), pers. comm.), and "Fletán Ártico" Spanish Survey in Svalbard ICES Div. IIb (Paz et al., 2004). The commercial survey data correspond to the period 2001-2003 in NAFO (Spanish bottom trawl fishery targeting Greenland halibut (Reinhardtius hippoglossoides), ICES (Spanish pair trawl fishery targeting Atlantic cod and Spanish bottom trawl fishery targeting northern shrimp (Pandalus borealis). The data obtained in the Pilot Action of Experimental Fishing developed in the Barents Sea-Svalbard (ICES Div. I and IIb) targeting American plaice in 1995 were also included (Durán and Román, 2000). The same biological data were used to calculate the condition and to obtain the parameters of the length-weight relationship.

TABLE 1. Number of individuals of $H$. platessoides sampled in $K_{r}$ study by area (NAFO Divs. 3LNO and 3M; ICES Div. IIb), year (1992-2003) and size range (cm).

\begin{tabular}{|c|c|c|c|c|c|c|c|c|c|c|c|c|c|c|}
\hline \multirow{2}{*}{\multicolumn{2}{|c|}{$\begin{array}{cc} & \text { Size range } \\
\text { Area } & (\mathrm{cm})\end{array}$}} & \multirow[b]{2}{*}{1992} & \multicolumn{11}{|c|}{ Year } & \multirow[b]{2}{*}{ Total } \\
\hline & & & 1993 & 1994 & 1995 & 1996 & 1997 & 1998 & 1999 & 2000 & 2001 & 2002 & 2003 & \\
\hline \multirow[t]{5}{*}{$3 \mathrm{M}$} & $20-29$ & 145 & 202 & 58 & 25 & 17 & 18 & 12 & 9 & 15 & 21 & 6 & 12 & 540 \\
\hline & $30-39$ & 573 & 366 & 488 & 308 & 239 & 171 & 127 & 102 & 127 & 208 & 42 & 195 & 2946 \\
\hline & $40-49$ & 430 & 373 & 397 & 307 & 244 & 176 & 211 & 208 & 191 & 224 & 93 & 233 & 3087 \\
\hline & $50-59$ & 60 & 88 & 110 & 117 & 60 & 67 & 90 & 130 & 72 & 114 & 82 & 95 & 1085 \\
\hline & Total & 1208 & 1029 & 1053 & 757 & 560 & 432 & 440 & 449 & 405 & 567 & 223 & 535 & 7658 \\
\hline \multirow[t]{6}{*}{3 LNO } & $20-29$ & & & & 511 & 184 & 801 & 372 & 102 & 136 & 246 & 479 & 667 & 3498 \\
\hline & $30-39$ & & & & 388 & 181 & 1076 & 542 & 134 & 206 & 594 & 515 & 531 & 4167 \\
\hline & $40-49$ & & & & 151 & 120 & 446 & 405 & 83 & 128 & 522 & 452 & 359 & 2666 \\
\hline & $50-59$ & & & & 28 & 67 & 82 & 161 & 29 & 54 & 276 & 273 & 168 & 1138 \\
\hline & $>=60$ & & & & 5 & 48 & 22 & 37 & 13 & 28 & 48 & 34 & 31 & 266 \\
\hline & Total & & & & 1083 & 600 & 2427 & 1517 & 361 & 552 & 1686 & 1753 & 1756 & 11735 \\
\hline \multirow[t]{5}{*}{ IIb } & $20-29$ & & & & 278 & & 295 & 183 & 252 & 167 & 374 & 415 & 474 & 2438 \\
\hline & $30-39$ & & & & 804 & & 135 & 91 & 91 & 59 & 294 & 465 & 333 & 2272 \\
\hline & $40-49$ & & & & 153 & & 7 & 3 & 4 & 3 & 21 & 78 & 38 & 307 \\
\hline & Total & & & & 1235 & & 437 & 277 & 347 & 229 & 689 & 958 & 845 & 5017 \\
\hline & Total & 1208 & 1029 & 1053 & 3075 & 1160 & 3296 & 2234 & 1157 & 1186 & 2942 & 2934 & 3136 & 24410 \\
\hline
\end{tabular}


TABLE 2. No. of individuals of H. platessoides sampled by area (NAFO Divs. 3LNO and 3M; ICES Div. IIb), year (1992-2003), data source $(\mathrm{CV}=$ commercial vessel; $\mathrm{RV}=$ research vessel $)$ and season.

\begin{tabular}{|c|c|c|c|c|c|c|c|c|c|c|c|c|c|c|c|}
\hline \multirow[b]{2}{*}{ Area } & \multirow{2}{*}{$\begin{array}{c}\text { RV } \\
\text { or } \\
\mathrm{CV}\end{array}$} & \multirow[b]{2}{*}{ Season } & \multicolumn{12}{|c|}{ Year } & \multirow[b]{2}{*}{ Total } \\
\hline & & & 1992 & 1993 & 1994 & 1995 & 1996 & 1997 & 1998 & 1999 & 2000 & 2001 & 2002 & 2003 & \\
\hline \multirow[t]{2}{*}{$3 \mathrm{M}$} & $\mathrm{RV}$ & Summer & 1208 & 1029 & 1053 & 757 & 560 & 432 & 440 & 449 & 405 & 567 & 223 & 535 & 7658 \\
\hline & Total & & 1208 & 1029 & 1053 & 757 & 560 & 432 & 440 & 449 & 405 & 567 & 223 & 535 & 7658 \\
\hline \multirow[t]{6}{*}{$3 \mathrm{LNO}$} & $\begin{array}{l}\mathrm{CV} \\
\mathrm{RV}\end{array}$ & $\begin{array}{l}\text { Spring } \\
\text { Snring }\end{array}$ & & & & 1083 & 600 & 2427 & 1517 & 361 & 552 & 720 & $\begin{array}{l}107 \\
866\end{array}$ & 1272 & $\begin{array}{r}107 \\
9398\end{array}$ \\
\hline & $\mathrm{CV}$ & Summer & & & & & & & & & & 100 & 126 & & 226 \\
\hline & RV & Summer & & & & & & & & & & & & 484 & 484 \\
\hline & $\mathrm{CV}$ & Autumn & & & & & & & & & & 456 & 654 & & 1110 \\
\hline & $\mathrm{CV}$ & Winter & & & & & & & & & & 410 & & & 410 \\
\hline & Total & & & & & 1083 & 600 & 2427 & 1517 & 361 & 552 & 1686 & 1753 & 1756 & 11735 \\
\hline \multirow[t]{5}{*}{$\mathrm{IIb}$} & $\mathrm{CV}$ & Spring & & & & & & & & & & & 192 & & 192 \\
\hline & $\mathrm{CV}$ & Summer & & & & 1235 & & & & & & & 145 & 65 & 1445 \\
\hline & $\mathrm{CV}$ & Autumn & & & & & & & & & & 142 & 158 & 85 & 385 \\
\hline & $\mathrm{RV}$ & Autumn & & & & & & 437 & 277 & 347 & 229 & 547 & 463 & 695 & 2995 \\
\hline & Total & & & & & 1235 & & 437 & 277 & 347 & 229 & 689 & 958 & 845 & 5017 \\
\hline Total & & & 1208 & 1029 & 1053 & 3075 & 1160 & 3296 & 2234 & 1157 & 1186 & 2942 & 2934 & 3136 & 24410 \\
\hline
\end{tabular}

The biological sampling was carried out on board, and the data collected for each individual were: length (TL to the nearest lower $\mathrm{cm}$ ), sex, maturity stage (immature, maturing, spawning and post-spawning), weight (g) and stomach repletion degree (empty, partial fullness, fullness). The individuals were compiled in size ranges of $10 \mathrm{~cm}$ each $(20-29,30-39,40-49,50-59$ and $\geq 60 \mathrm{~cm})$ to make analysis easier (Table 1). The maturity stage was determined by macroscopic analysis.

Data were grouped by seasons. In some cases it was not possible to complete the annual cycle (in Div. 3M and IIb) because there were not enough data. The available data for the spring included the months of April and May; those for the summer included the period from June to August; those for the autumn included the period from September to November; and those for the winter included the months of December and January. The inter-annual comparisons were only made when at least, a two year series for the same season was available.

Individuals smaller than $20 \mathrm{~cm}$ were not taken into account, because their weight showed a very high varia- tion caused by an error found in the weight system used on board. In some cases, individuals $\geq 60 \mathrm{~cm}$ were not considered due to the small amount of individuals in the sample.

Divisions 3N, $3 \mathrm{O}$ and $3 \mathrm{~L}$ data were studied as a whole, because it is consider as one stock for this species (Anon., 2004).

A condition index was calculated because it provides a useful assessment of the 'plumpness' and physiological well-being of fishes. The power function is calculated in order to obtain the expected weight $\left(W^{\prime}\right)$, using the mathematical description of length-weight relationship for all the individuals in each group and for every comparison carried out. That is: a first regression for all the individuals together to carry out a first general comparison among the three areas making no differences according to sex; a second regression for all data of the samplings carried out in summer; a new regression for all the females (in the three areas) and another different one for all males (in the three areas); and finally other size-weight regressions were calculated for individuals 
in each area for the independent study of each of the three areas.

$$
W^{\prime}=a L^{b}
$$

where: $\quad L$ is the total length $(\mathrm{cm})$ of the individual $i$

$a$ is the intercept

$b$ is the exponent

The Relative Condition Factor $\left(K_{r}\right)$ is calculated to compare fishes of the same species of different lengths, sex, locations and years (Le Cren, 1951).

$$
K_{r}=W / W^{\prime}
$$

where: $\quad W$ is the observed weight of the individual $i$

$W^{\prime}$ is the predicted weight based on weightlength equation for the individual $i$

The GLM Univariate procedure (General Linear Model) has been used to test the hypothesis that the means of the Relative Condition Factor of several groups are not significantly different. General Linear Model Univariate procedure is an ANOVA of two or more ways, where the inter-group variance is divided in main effects and interactions. The main effects are the effects of each of the independent variables, and the interactions are the intersections among the independent variables. Null hypotheses on the effects of variables in the means of several groups with an only dependent variable can be tested with this procedure. Interactions among factors, as well as the effects of individual factors, can be studied.

American plaice feeding habits were studied using the same research survey data: 2119 individuals in the 1993-2003 period in Div. 3M; 5262 individuals in the 2002-2003 period in Div. 3LNO; and 1162 individuals in the 2002-2003 period in Div. IIb (Table 3). In each haul, a maximum of 10 stomachs in each $10 \mathrm{~cm}$ length range were analysed. Fish whose stomachs were everted or contained prey ingested in the fishing gear were discarded. Specimens that presented total or partial regurgitation were taken into account to estimate the emptiness indices. The methodology was the same since 1993 (Rodríguez-Marín et al., MS 1994).

In this study about the feeding habits, the data for each predator collected were: total length (nearest lower $\mathrm{cm}$ ); volume of the stomach content, quantified in $\mathrm{cm}^{3}$ using a trophometer (Olaso, 1990); the percentage of each prey in the total volume, and digestion stage and number of each prey. Prey were identified to species

TABLE 3. Characteristics of individuals of $H$. platessoides sampled in the feeding study by area (NAFO Divs. 3LNO and 3M;

\begin{tabular}{|c|c|c|c|c|c|c|c|c|c|c|c|}
\hline Survey & Div. & Year & $\begin{array}{c}\text { No. } \\
\text { Empty }\end{array}$ & $\begin{array}{l}\text { No. } \\
\text { Full }\end{array}$ & $\begin{array}{l}\text { No. } \\
\text { Reg. }\end{array}$ & Total & $\% \mathrm{FI}$ & $\begin{array}{c}\text { Size } \\
\text { range } \\
(\mathrm{m})\end{array}$ & $\begin{array}{l}\text { Depth } \\
\text { range } \\
\text { (m) }\end{array}$ & $\begin{array}{c}\text { No. } \\
\text { of } \\
\text { hauls }\end{array}$ & $\begin{array}{c}\text { No. } \\
\text { Prey } \\
\text { Items }\end{array}$ \\
\hline "Flemish Cap" & $3 \mathrm{M}$ & 1993 & 71 & 338 & 0 & 409 & 82.6 & $18-59$ & $148-639$ & 50 & 22 \\
\hline "Flemish Cap" & $3 \mathrm{M}$ & 1996 & 63 & 193 & 0 & 256 & 75.4 & $12-60$ & $135-450$ & 40 & 30 \\
\hline "Flemish Cap" & $3 \mathrm{M}$ & 1997 & 41 & 137 & 0 & 178 & 77.0 & $12-58$ & $133-324$ & 28 & 26 \\
\hline "Flemish Cap" & $3 \mathrm{M}$ & 1998 & 15 & 126 & 1 & 142 & 89.4 & $21-55$ & $139-477$ & 30 & 25 \\
\hline "Flemish Cap" & $3 \mathrm{M}$ & 1999 & 20 & 214 & 0 & 234 & 91.5 & $26-60$ & $133-377$ & 33 & 28 \\
\hline "Flemish Cap" & $3 \mathrm{M}$ & 2000 & 43 & 172 & 15 & 230 & 81.3 & $5-56$ & $228-589$ & 40 & 31 \\
\hline "Flemish Cap" & $3 \mathrm{M}$ & 2001 & 91 & 229 & 0 & 320 & 71.6 & $12-59$ & $132-631$ & 52 & 37 \\
\hline "Flemish Cap" & $3 \mathrm{M}$ & 2002 & 34 & 135 & 0 & 169 & 79.9 & $25-57$ & $131-352$ & 50 & 28 \\
\hline "Flemish Cap" & $3 \mathrm{M}$ & 2003 & 86 & 95 & 0 & 181 & 52.5 & $12-58$ & $130-534$ & 43 & 18 \\
\hline "Platuxa" & $3 \mathrm{NO}$ & 2002 & 1369 & 868 & 0 & 2237 & 38.8 & $6-67$ & $39-1460$ & 85 & 42 \\
\hline "Platuxa" & $3 \mathrm{NO}$ & 2003 & 1236 & 1290 & 0 & 2526 & 51.1 & $5-72$ & $44-888$ & 80 & 41 \\
\hline "Fletán negro-3L" & $3 \mathrm{~L}$ & 2003 & 321 & 178 & 0 & 499 & 35.7 & $6-54$ & $118-864$ & 25 & 18 \\
\hline \multirow[t]{2}{*}{ "Fletán Ártico" } & II b & 2002 & 465 & 13 & 0 & 478 & 2.7 & $9-42$ & $530-1118$ & 81 & 11 \\
\hline & II b & 2003 & 659 & 24 & 1 & 684 & 3.5 & $8-47$ & $560-1117$ & 76 & 11 \\
\hline \multirow[t]{3}{*}{ Total } & Div 3M & 1993-2003 & 464 & 1639 & 16 & 2119 & 78.1 & $5-60$ & $130-639$ & 366 & 70 \\
\hline & Div. 3LNO & $2002-2003$ & 2926 & 2336 & 0 & 5262 & 44.4 & $5-72$ & $39-1460$ & 190 & 50 \\
\hline & Div. II b & $2002-2003$ & 1124 & 37 & 1 & 1162 & 3.3 & $8-47$ & $530-1118$ & 157 & 17 \\
\hline
\end{tabular}
ICES Div. IIb) and year (1993-2003). \% FI = Feeding intensity; No. Reg. = No. of regurgitated stomachs. 
when the digestion stage permitted it, or to the lowest possible taxonomic level.

The Feeding Intensity Index (FI) is the percentage of individuals with stomach contents and it is calculated to analyse the feeding intensity for each predator: $F I=n / N_{t} \times 100$, where $n$ is the number of individuals with stomach contents and $N_{t}$ is the total number of individuals sampled.

The importance of each prey taxa in the stomach contents was evaluated using the percentage in volume: $V=v / V_{t} \times 100$, where $v$ is the volume of a determined prey, and $V_{t}$ is the total volume of prey. The volumetric method overvalues the importance of large organisms (Hyslop, 1980).

\section{Results}

When the condition data of the individuals of the three areas were compared, Relative Condition Factor $\left(K_{r}\right)$ value showed significant differences with regard to the area, year, season, size range and sex. Not all interactions between factors were significant (Table 4A).

The annual total mean of the Relative Condition Factor value in summer throughout the studied period in Div. 3M decreased substantially. In Div. 3LNO in spring, $K_{r}$ showed a general and slightly decreasing tendency

TABLE 4. Tests of between-subjects effects of $H$. platessoides sampled.

\begin{tabular}{|c|c|c|c|c|c|c|c|}
\hline \multicolumn{4}{|c|}{ A.- Condition data of the individuals of the three areas } & \multicolumn{4}{|c|}{ B.- Condition data of the females of the three areas } \\
\hline \multirow{2}{*}{\begin{tabular}{|l} 
Source \\
Area \\
\end{tabular}} & \multirow{2}{*}{$\frac{F}{24.6}$} & \multicolumn{2}{|l|}{ Sig. } & \multirow{2}{*}{\begin{tabular}{|l} 
Source \\
Area
\end{tabular}} & \multirow{2}{*}{$\begin{array}{c}\mathrm{F} \\
10.1 \\
\end{array}$} & \multicolumn{2}{|l|}{ Sig. } \\
\hline & & $\mathrm{p} \leq 0.0001$ & $\mathrm{~s}$ & & & $\mathrm{p} \leq 0.0001$ & $\mathrm{~s}$ \\
\hline Year & 9.6 & $\mathrm{p} \leq 0.0001$ & $\mathrm{~s}$ & Year & 12.8 & $\mathrm{p} \leq 0.0001$ & $\mathrm{~s}$ \\
\hline Season & 21.7 & $\mathrm{p} \leq 0.0001$ & $\mathrm{~s}$ & Season & 26.6 & $\mathrm{p} \leq 0.0001$ & $\mathrm{~s}$ \\
\hline Size range & 4.4 & $\mathrm{p} \leq 0.001$ & $\mathrm{~s}$ & Size range & 4.6 & $\mathrm{p} \leq 0.001$ & $\mathrm{~s}$ \\
\hline Sex & 20.2 & $\mathrm{p} \leq 0.0001$ & $\mathrm{~s}$ & Area $*$ Y ear $*$ Size range & 1.2 & $p>0.05$ & ns \\
\hline Y ear * Season * Size range* Sex & 3.1 & $\mathrm{p} \leq 0.05$ & $\mathrm{~s}$ & Year* Season* Size range & 9.1 & $\mathrm{p} \leq 0.0001$ & $\mathrm{~s}$ \\
\hline \multirow{2}{*}{\multicolumn{4}{|c|}{ C.- Condition data of the males of the three areas }} & Area* Season* Size range & 4.9 & $\mathrm{p} \leq 0.001$ & $\mathrm{~s}$ \\
\hline & & & & \multicolumn{4}{|c|}{ D.- Condition data of the individuals of the three areas in summer } \\
\hline Source & $\mathrm{F}$ & Sig. & & Source & $F$ & Sig. & \\
\hline Area & 14.1 & $\mathrm{p} \leq 0.0001$ & $\mathrm{~s}$ & Area & 82171.4 & $\mathrm{p} \leq 0.0001$ & $\mathrm{~s}$ \\
\hline Year & 4.2 & $\mathrm{p} \leq 0.0001$ & $\mathrm{~s}$ & Year & 1.7 & $p>0.05$ & ns \\
\hline Season & 4.1 & $\mathrm{p} \leq 0.01$ & $\mathrm{~s}$ & Size range & 275.1 & $\mathrm{p} \leq 0.0001$ & $\mathrm{~s}$ \\
\hline Size range & 1.4 & $p>0.05$ & ns & Sex & 2.9 & $p>0.05$ & ns \\
\hline A rea $*$ Y ear $*$ Size range & 3.2 & $\mathrm{p} \leq 0.05$ & $\mathrm{~s}$ & A rea * Y ear * Size range* Sex & 2.8 & $\mathrm{p} \leq 0.05$ & $\mathrm{~s}$ \\
\hline Y ear * Season * Size range & 2.0 & $p>0.05$ & ns & & & & \\
\hline Area * Season * Size range & 0.6 & $p>0.05$ & ns & & & & \\
\hline \multicolumn{4}{|c|}{ E.- Condition data of the individuals of Div. 3M } & \multicolumn{4}{|c|}{ F.- Condition data of the individuals of Divs. 3 L NO } \\
\hline Source & $\mathrm{F}$ & Sig. & & Source & $\mathrm{F}$ & Sig. & \\
\hline Sex & 13.7 & $\mathrm{p} \leq 0.0001$ & $\mathrm{~s}$ & Sex & 26.9 & $\mathrm{p} \leq 0.0001$ & $\mathrm{~s}$ \\
\hline Size range & 6.0 & $\mathrm{p} \leq 0.0001$ & $\mathrm{~s}$ & Season & 13.2 & $\mathrm{p} \leq 0.0001$ & $\mathrm{~s}$ \\
\hline Y ear & 13.7 & $\mathrm{p} \leq 0.0001$ & $\mathrm{~s}$ & Size range & 6.6 & $\mathrm{p} \leq 0.0001$ & $\mathrm{~s}$ \\
\hline Sex * Size range* Y ear & 1.6 & $\mathrm{p} \leq 0.05$ & $\mathrm{~s}$ & Y ear & 6.3 & $\mathrm{p} \leq 0.0001$ & $\mathrm{~s}$ \\
\hline \multirow{2}{*}{\multicolumn{4}{|c|}{ G.- Condition data of the individuals of Div. IIb }} & Sex* Season $*$ Size range* Y ear & 4.0 & $\mathrm{p} \leq 0.01$ & $\mathrm{~s}$ \\
\hline & & & & & & & \\
\hline Source & $\mathrm{F}$ & \multicolumn{2}{|l|}{ Sig. } & & & & \\
\hline Sex & 0.1 & $p>0.05$ & ns & & & & \\
\hline Season & 19.3 & $\mathrm{p} \leq 0.0001$ & $\mathrm{~s}$ & & & & \\
\hline Size range & 0.2 & $p>0.05$ & ns & & & & \\
\hline Y ear & 3.7 & $\mathrm{p} \leq 0.0001$ & $\mathrm{~s}$ & & & & \\
\hline Sex* Season* Size range* Y ear & 0.004 & $p>0.05$ & ns & & & & \\
\hline
\end{tabular}


with a period of increase between 1999 and 2001, and it increased in Div. IIb in the autumn. Female presented $K_{r}$ values which were slightly higher than the values in males in the three areas. The biomass in Div. $3 \mathrm{M}$ in the same period has declined to very low levels, however, it showed an increase in the last year (Saborido and Vázquez, MS 2003; Casas, MS 2004). There was a significant positive correlation between biomass and condition in Div. $3 \mathrm{M}$. The estimated biomass in divisions
Div. 3NO (Gónzález Troncoso et al., MS 2004) showed an increase in the period 1998-2001 just like the condition. Although trends were similar there was not a significant correlation. This relation in Div. IIb was much more irregular (Fig. 1).

When the condition data of the females of the three areas were compared, Relative Condition Factor values showed significant differences with regard to area,
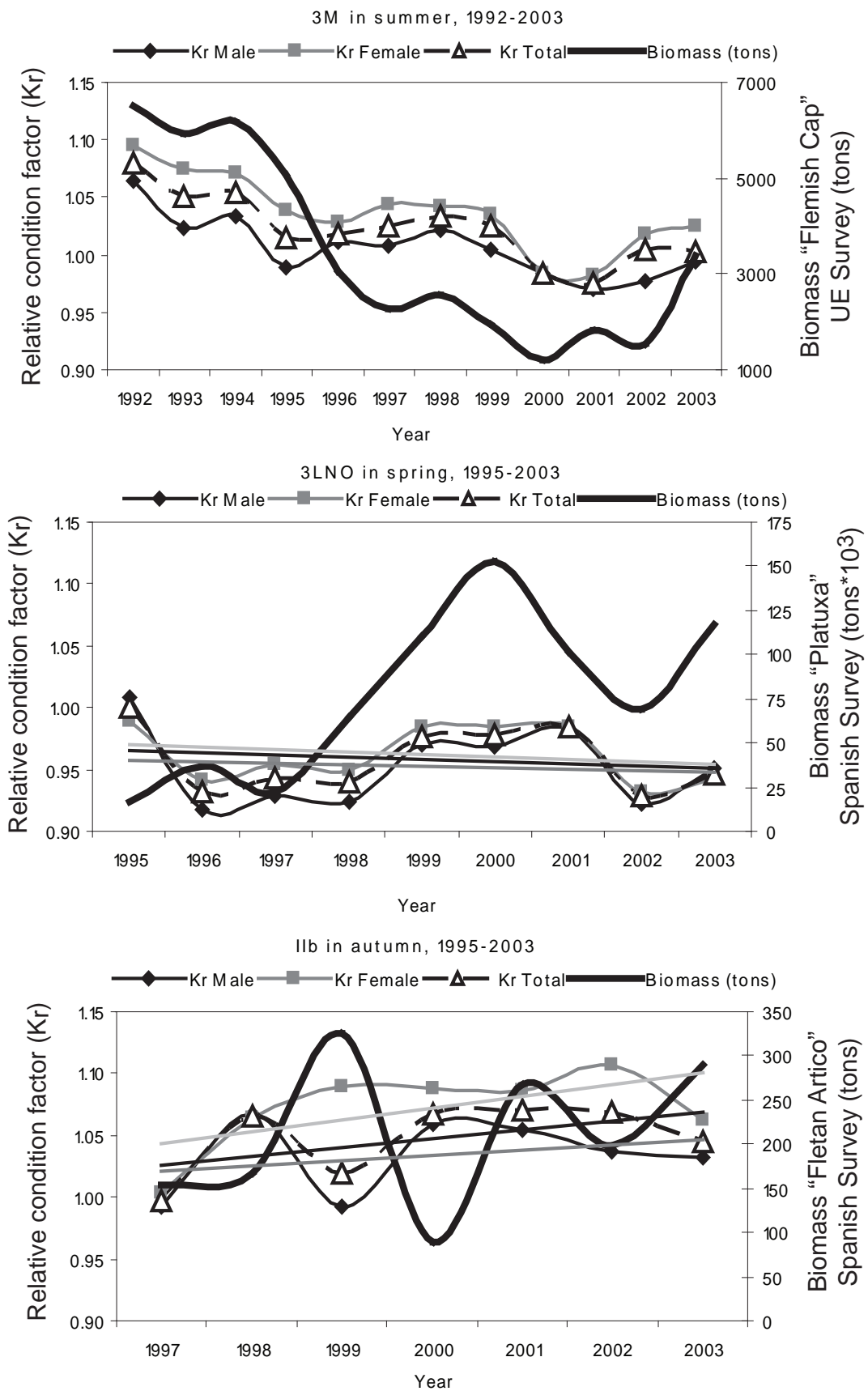

Fig. 1. Mean Relative Condition Factor and biomass estimated of $H$. platessoides by year. 
season, size range and year. Not all the interactions of these factors were significant (Table 4B). $K_{r}$ value of the males showed no significant differences with regard to size range (Table 4C). Relative Condition Factor value of females and males showed significant seasonal variation. Individuals showed a lower condition in the period spring-summer, but the high condition in summer in Div. $3 \mathrm{M}$ compared with the other areas is remarkable (Fig. 2). The condition data of individuals of the summer samplings and years 1995 and 2000-2003 for the three areas were compared and Relative Condition Factor value showed significant differences with the interactions of these four factors (Table 4D).

\section{Relative Condition in Division 3M (Flemish Cap)}

The summer $K_{r}$ value in this division showed significant differences in the interaction with regard sex, size range and year (Table 4E). This index showed a gradual loss of condition which was more remarkable in the period 2000-2002, and mainly in males. More annual oscillations are observed in females $<40 \mathrm{~cm}$ TL and in males $<30 \mathrm{~cm}$ TL. In bigger sizes the general tendency shows a constant decrease (Fig. 3).

\section{Relative Condition in Division 3LNO}

The mean Relative Condition Factor value presented significant differences with regard to sex, year, season and size range, and the interactions of these four effects (Table 4F). Females showed a better condition than males in every season. Both sexes increased their condition from spring to autumn. This behaviour becomes clearer as the size increases. In individuals $<30 \mathrm{~cm}$ TL more interannual variations are shown (Fig. 4).

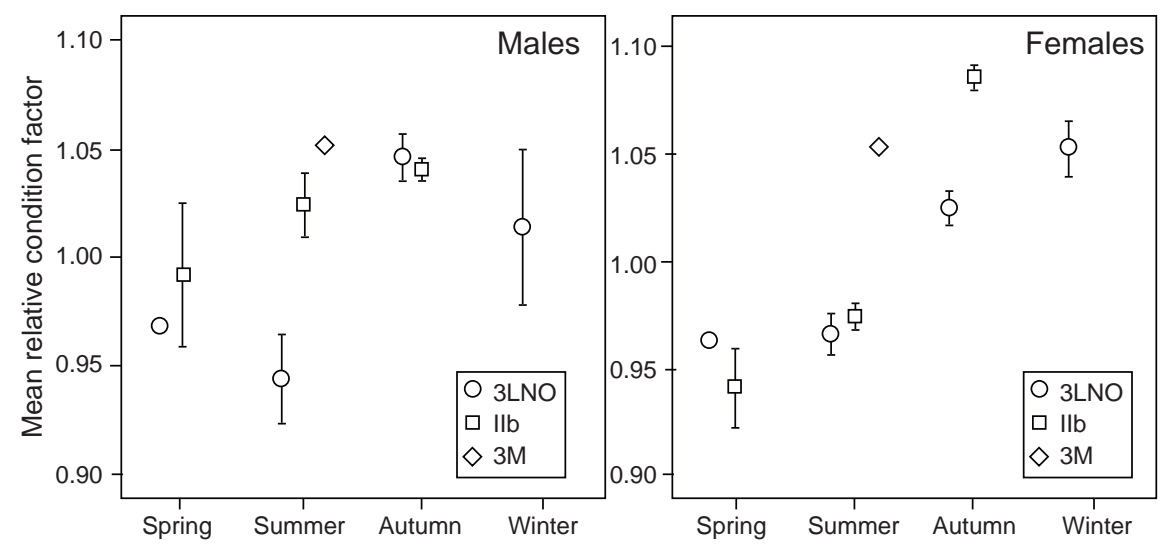

Fig. 2. Mean Relative Condition Factor (with 95\% confidence interval) of male and female H. platessoides by season in each area. The sampled periods were: 1992-2003 in Div. 3M, and 1995-2003 in Div. 3LNO and IIb.
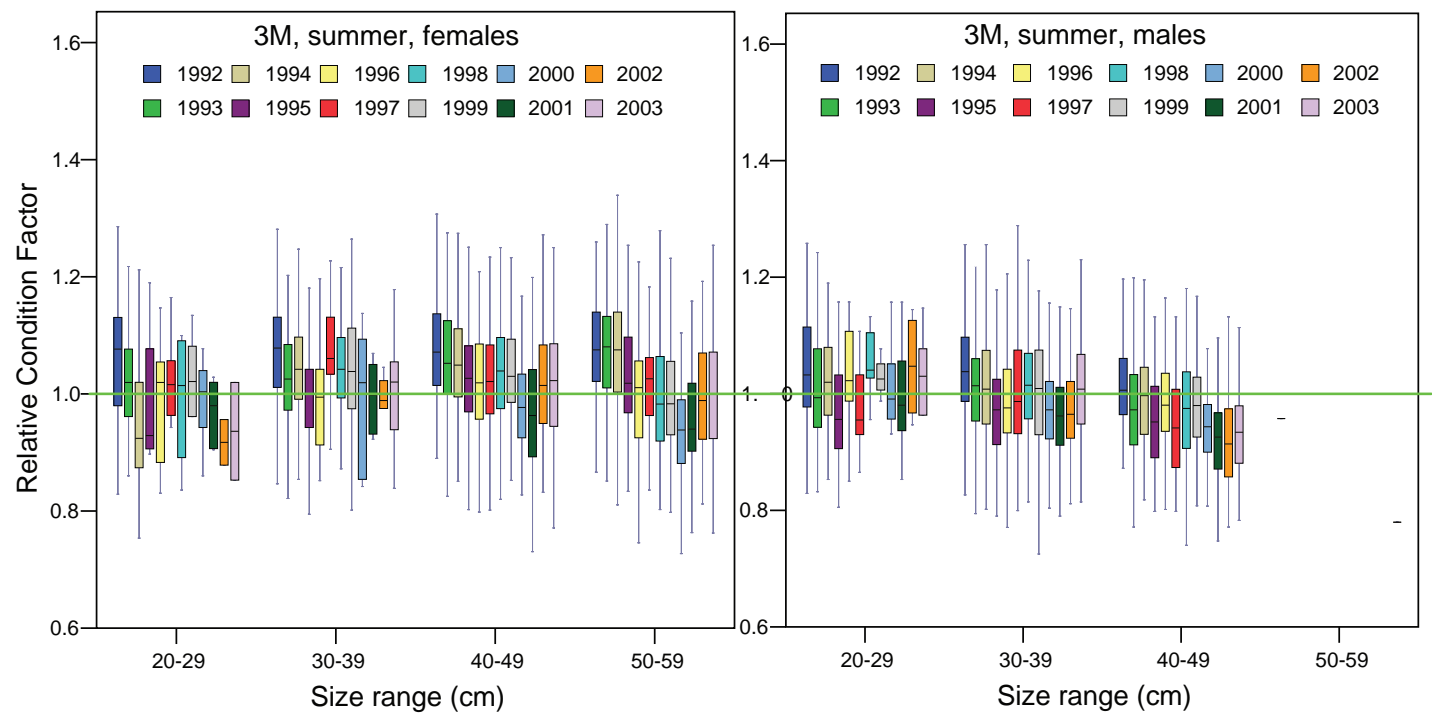

Fig. 3. Mean Relative Condition Factor of females and males of H. platessoides by year and size range $(\mathrm{cm})$ in summer in Div. 3M from 1992 to 2003. Box plots show the median and interquartile range. 

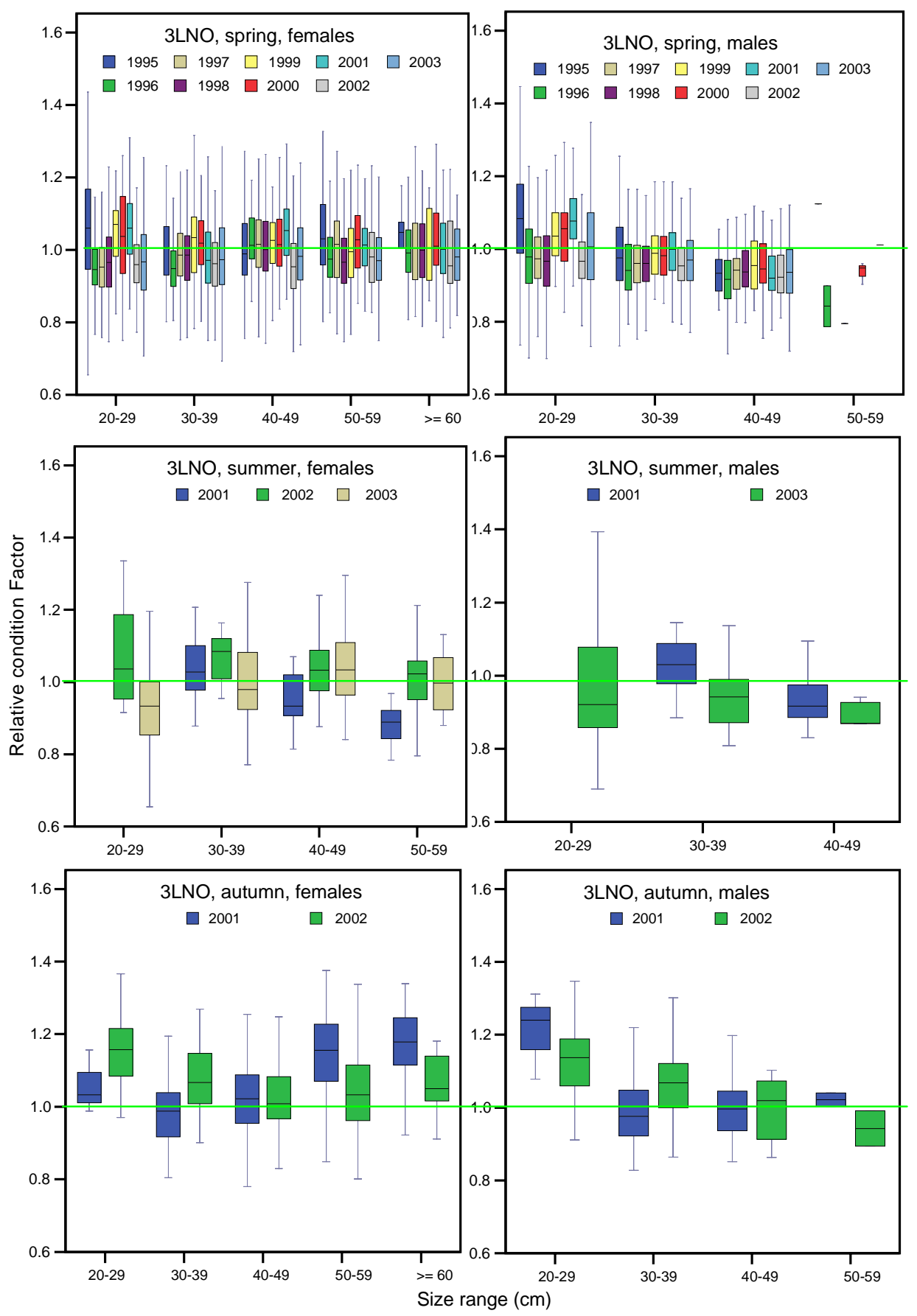

Fig. 4. Mean Relative Condition Factor of females and males of H. platessoides by year and size range $(\mathrm{cm})$ in each season in Div. 3LNO. Box plots show the median and interquartile range.

\section{Relative Condition in Division IIb}

In this Division, this value was significantly different with regard to year and season. However, no significant differences were found with regard to the interactions of these effects (Table 4G). Condition improves remarkably in the period from summer to autumn for both sexes, mainly in females $\geq 30 \mathrm{~cm}$ TL. Annual oscil- lations were not seen equally in the different size ranges (Fig. 5).

\section{Relative Condition in Relation to the Maturity and the Feeding Intensity}

Condition and maturity in males showed clear and similar connections in the different areas, with immature 


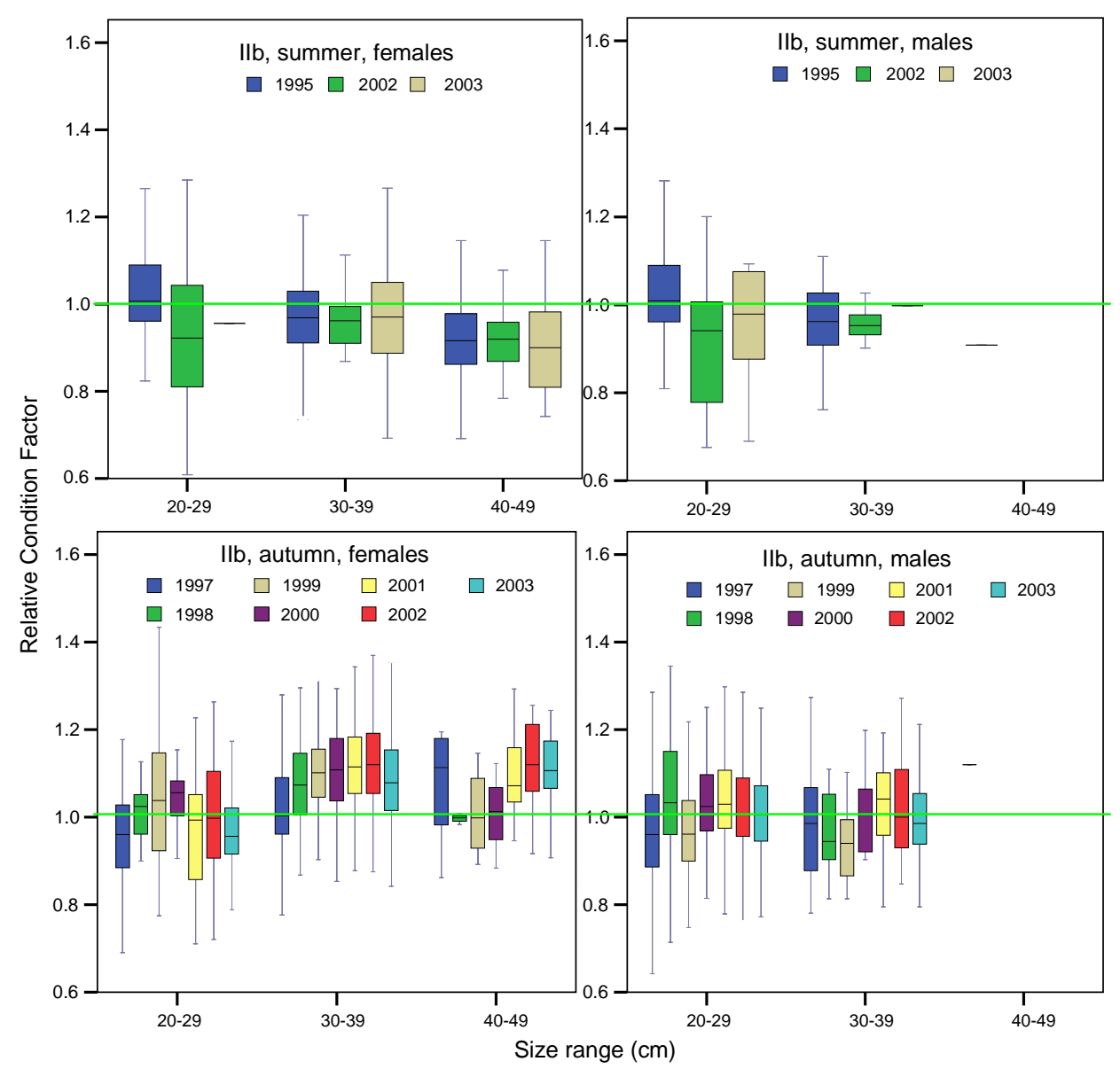

Fig. 5. Mean Relative Condition Factor of females and males of H. platessoides by year and size range $(\mathrm{cm})$ in each season in Div. IIb. Box plots show the median and interquartile range.

individuals in better condition than adults, and the adults loose condition as they move farther in the reproductive cycle (Fig. 6). Condition and feeding intensity of spawning females and males showed an inverse relation with a decrease in the feeding intensity when the condition increases and vice versa (Fig. 7).

\section{Feeding Habits Study}

Data of feeding habits showed a high annual feeding intensity in summer in Div. 3M (78\%) and a very low one in autumn in Div. IIb (3\%). The specific variety of prey was remarkably high in Div. 3M (70 different items) and low in Div. IIb (17 different items) (Table 3). General tendency of the annual Relative Condition Factor value and feeding intensity value for the same periods and seasons was similar (Fig. 8).

The main prey groups by volume in the stomach contents in Div. 3M for the studied period (1993-2003) were Echinodermata (Ophiuroidea, 56\%) and Crustacea (mainly hyperiids with 13\%). Echinodermata predominated in sizes $\geq 20 \mathrm{~cm} \mathrm{TL}$, and fish (5\%) were more abundant in individuals $<20 \mathrm{~cm}$ TL (Table 5 and Fig. 9). Main prey composition in the diet has changed in the recent years. Echinodermata was the main prey during the 1993-99 period, however it presented a notable decrease in the stomach contents from the year 2000, being substituted by crustaceans and other invertebrates (Fig. $10)$. The main prey groups in Div. 3LNO in the studied period 2002-2003 were fish (62\%), mainly Ammodytes dubbius (40\%), and crustaceans (15\%); equinoderms (11\%) were also important, mainly mysids and sand dollars (Echinarachnius parma). Crustaceans predominated in sizes $<20 \mathrm{~cm}$ TL and fish in sizes $\geq 30 \mathrm{~cm}$ TL (Table 6 and Fig. 9).

And finally, the most important prey in the diet of American plaice in Div. IIb in the period 2002-2003 


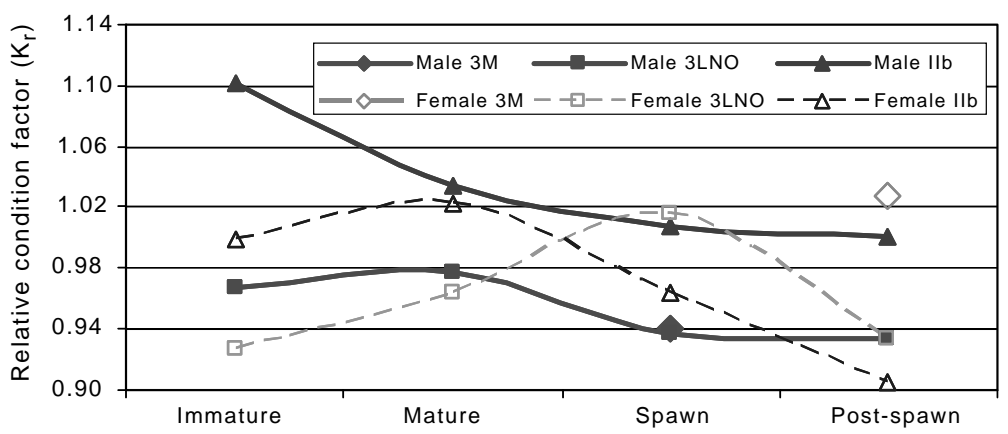

Fig. 6. Mean Relative Condition Factor of $H$. platessoides by sex and maturity in each area.

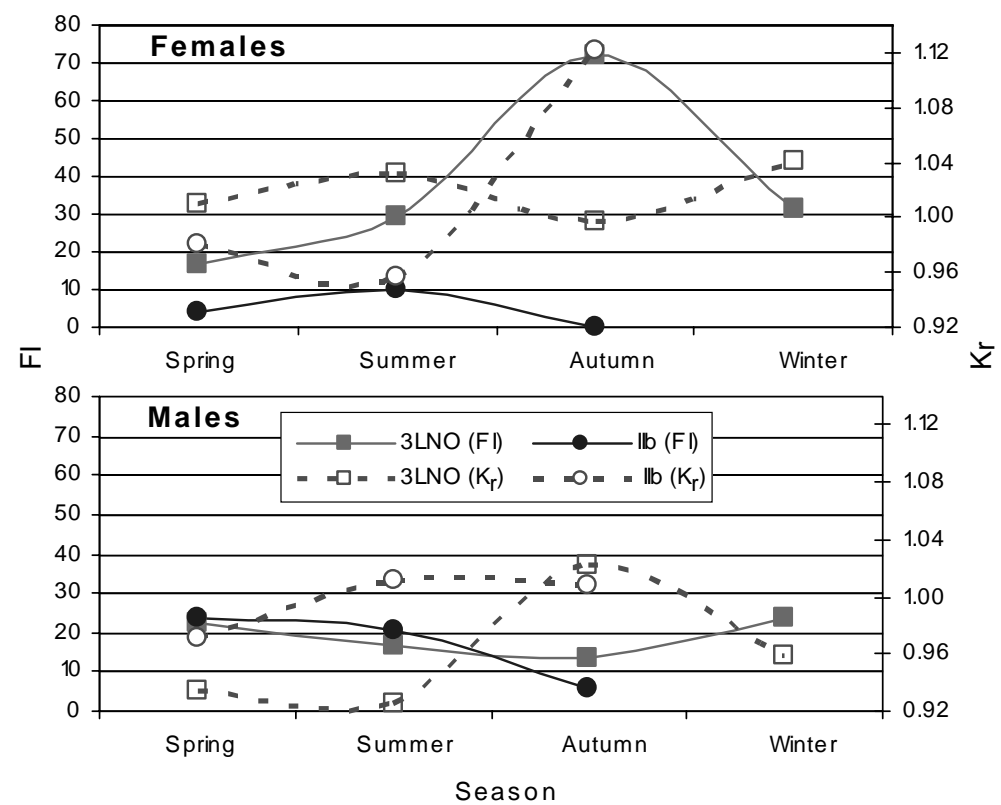

Fig. 7. Feeding Intensity (FI\%) and Mean Relative Condition Factor $\left(K_{r}\right)$ of spawning females and males of $H$. platessoides

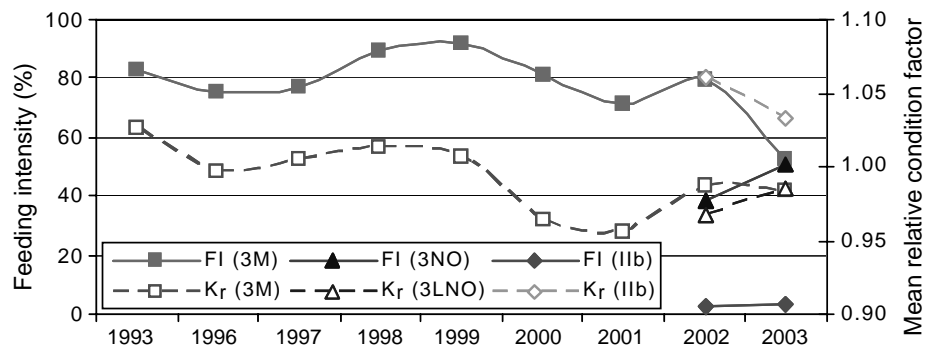

Fig. 8. Feeding Intensity in the feeding habits data and Relative Condition Factor of $H$. platessoides in North Atlantic area. NAFO (Div. 3M, summer 1993-2003; Div. 3NO, spring 2002-2003) and ICES (Div. IIb, autumn 2002-2003). 
TABLE 5. Volume (\%) of the main preys for H. platessoides by length groups in Flemish Cap (Div. 3M, 19932003).

\begin{tabular}{|c|c|c|c|c|c|c|}
\hline \multirow[b]{2}{*}{ Prey } & \multicolumn{5}{|c|}{ Size range $(\mathrm{cm})$} & \multirow[b]{2}{*}{ Total } \\
\hline & $10-19$ & $20-29$ & $30-39$ & $40-49$ & $>=50$ & \\
\hline PISCES & 75.5 & 4.8 & 8.3 & 5.0 & 2.5 & 4.8 \\
\hline Lumpenus lumpretaeformis & 67.3 & 3.7 & 3.3 & 2.7 & 0.3 & 2.0 \\
\hline Other Pisces & 8.2 & 1.2 & 5.0 & 2.3 & 2.2 & 2.8 \\
\hline CRUSTACEA & 10.5 & 45.9 & 22.2 & 22.6 & 23.4 & 23.2 \\
\hline Hyperiidea & & 0.3 & 6.7 & 16.1 & 12.1 & 12.5 \\
\hline Euphausiacea & & 2.6 & 1.4 & 1.2 & 0.7 & 1.1 \\
\hline Pandalus borealis & 2.5 & 21.6 & 8.6 & 4.4 & 9.8 & 7.5 \\
\hline Other crustaceans & 8.0 & 21.4 & 5.5 & 0.9 & 0.8 & 2.1 \\
\hline MOLLUSCA & & 0.3 & 1.3 & 1.1 & 0.4 & 0.9 \\
\hline ECHINODERMATA & 14.0 & 44.2 & 64.5 & 62.9 & 52.7 & 59.2 \\
\hline Ophiuroidea & 14.0 & 43.9 & 62.8 & 60.3 & 48.8 & 56.3 \\
\hline Echinoidea regularia & & 0.3 & 1.4 & 1.9 & 2.1 & 1.8 \\
\hline Other Echinodermata & & & 0.2 & 0.8 & 1.8 & 1.0 \\
\hline OTHER INVERTEBRATES & & 4.7 & 3.4 & 8.1 & 21.0 & 11.8 \\
\hline Polychaeta & & 2.3 & 2.0 & 3.7 & 2.7 & 3.0 \\
\hline Chaetognata & & 1.5 & 1.0 & 2.0 & 1.9 & 1.8 \\
\hline Ctenophora & & & & 1.9 & 15.9 & 6.6 \\
\hline Other invertebrates & & 0.9 & 0.3 & 0.6 & 0.4 & 0.5 \\
\hline OTHER & & 0.1 & 0.3 & 0.2 & 0.1 & 0.2 \\
\hline No. indivs. sampled with stomach contents & 14 & 125 & 528 & 657 & 315 & 1639 \\
\hline
\end{tabular}

were crustaceans (47\%), mainly Pandalus borealis (14\%) and Euphausiacea (13\%), and fish (27\%), mainly Melanogrammus aeglefinus (22\%). Individuals $<30 \mathrm{~cm}$ TL preyed on crustaceans and equinoderms, and individuals $\geq 30 \mathrm{~cm}$ TL preyed on fish and crustaceans in similar quantities (Table 7 and Fig. 9).

\section{Discussion}

Literature shows that the spawning period of American plaice varies geographically, taking place at the beginning of April on the Flemish Cap, earlier than on the Grand Bank (at the end of May) and in Labrador (at the beginning of June) (Zamarro, 1992). Walsh (1994) compared western and eastern North Atlantic American plaice populations and found that the southern populations of this area presented a quick growth, early maturation and their spawning took place from the beginning of winter until spring, the northern populations as presented a slow growth, whereas late maturation and their spawning took place in the spring-summer period.
Morgan (2001) examined samples from Div. 3LNO in the period 1971-99 and found low inter-annual variation in the spawning, except in recent years, when the spawning took place in deeper waters and it was more abundant in Div. 3NO than in Div. 3L. In Div. 3L, spawning was later (May) than in Div. 3NO (April) with later spawning in the 1990s. The spawning period took up a wide seasonal period. Spawning females were found from February to August, and they were even observed in the months of November and December. This author found post-spawning individuals all the year round, with the biggest proportion of them from April to August. Individuals from maturing to spawning stages were also found in all the seasons, and a high proportion of mature individuals appeared from September to December. This aspect of the duration of the spawning has been noted by other authors (Johnson et al., MS 1999).

Walsh $(1994,1996)$ indicated that spawning in the eastern North Atlantic (in the Barents Sea and Svalbard area) began in March and ended in July, and had a peak 

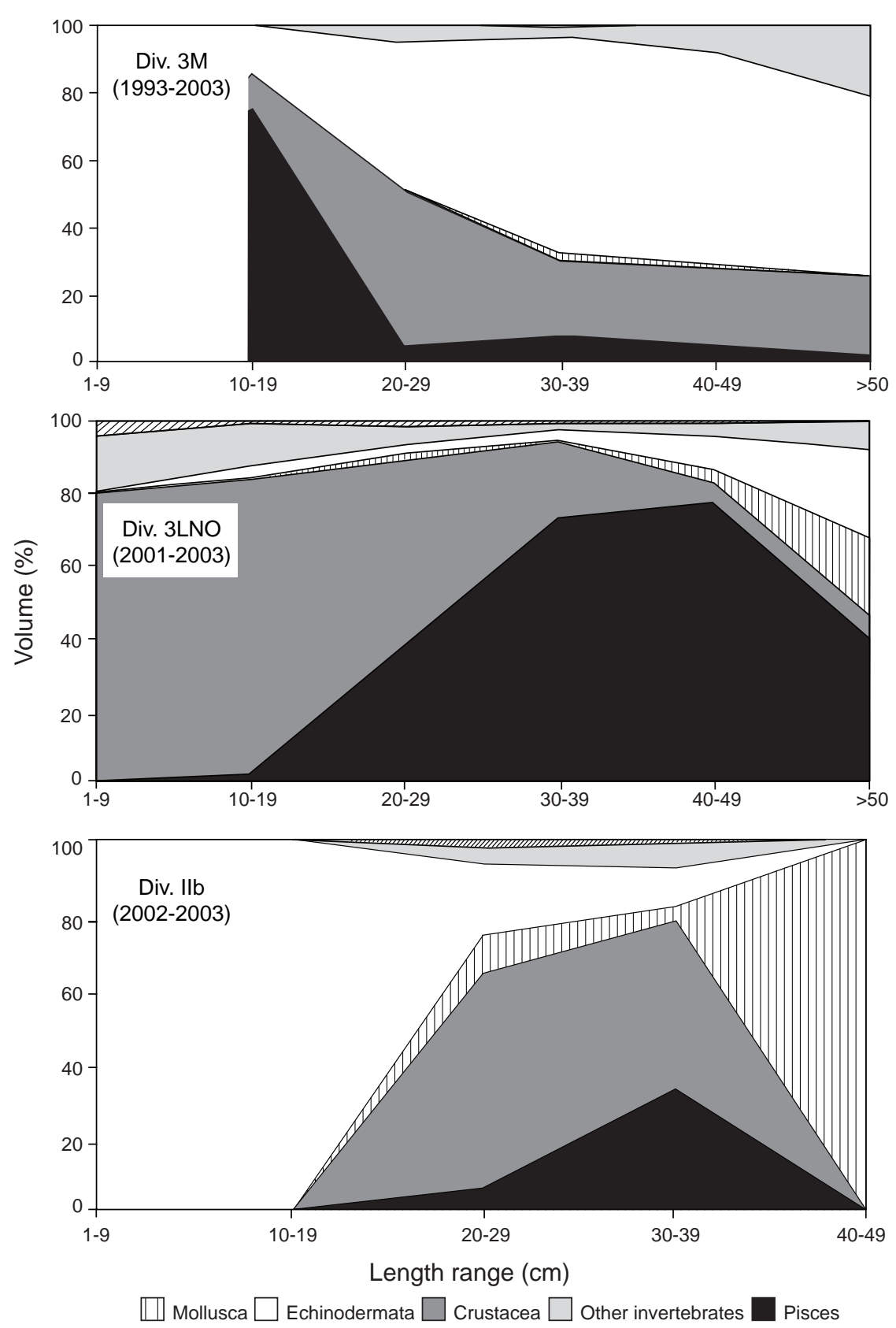

Fig. 9. Volume $(\%)$ of the most prey groups by size range $(\mathrm{cm})$ for $H$. platessoides in NAFO (Div. 3M, 1993-2003; and 3LNO, 2001-2003) and ICES (Div. IIb, 20022003).

in spring. These populations were much larger in age and size at maturity than in other areas.

Taking into account the $K_{r}$ values obtained throughout the studied period for the three areas of the North Atlantic, two groups of individuals would be expected: the smaller and the bigger size for the first maturation. The first ones should present low $K_{r}$ values and small seasonal and inter-annual variability, while the others should present high values with seasonal fluctuations. These two groups would correspond to two moments of the vital cycle; the first period, with important somatic growth and scarce reserves, in which the energy is used in growth; and another period of small somatic growth, in which the energy is used in reproductive functions with a small rate of growth. Thus, the hypothetical mechanism 
GONZÁLEZ et al.: Condition and Feeding of American Plaice

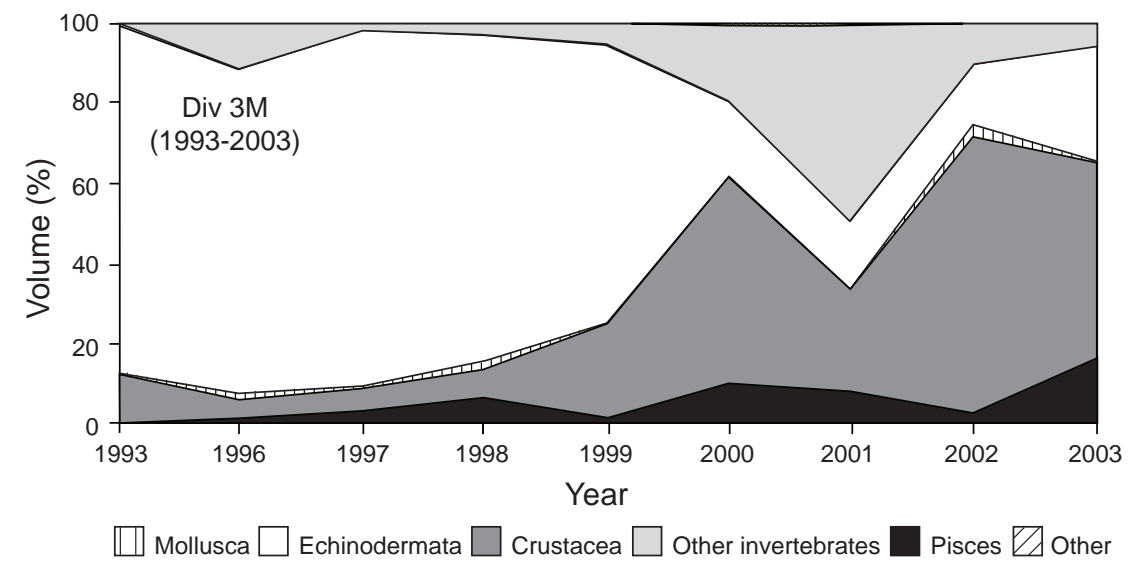

Fig. 10. Volume (\%) of the main prey groups for H. platessoides by year in Flemish Cap (Div. 3M), 1993-2003.

TABLE 6. Volume (\%) of the main preys for H. platessoides by length groups in NAFO (Divs. 3LNO, 2002-03).

\begin{tabular}{|c|c|c|c|c|c|c|c|}
\hline \multirow[b]{2}{*}{ Preys } & \multicolumn{6}{|c|}{ Size range $(\mathrm{cm})$} & \multirow[b]{2}{*}{ Total } \\
\hline & $1-9$ & $10-19$ & $20-29$ & $30-39$ & $40-49$ & $>=50$ & \\
\hline PISCES & & 2.5 & 37.0 & 73.3 & 77.6 & 41.1 & 62.4 \\
\hline Ammodytes dubbius & & & 17.0 & 36.9 & 52.8 & 32.9 & 40.2 \\
\hline Mallotus villosus & & & 14.0 & 28.3 & 22.5 & 8.0 & 18.9 \\
\hline Liparis sp. & & 0.3 & 1.9 & 5.4 & 1.1 & & 1.8 \\
\hline Other Pisces & & 2.2 & 4.1 & 2.7 & 1.1 & 0.2 & 1.5 \\
\hline CRUSTACEA & 80.1 & 81.5 & 52.1 & 21.0 & 5.7 & 5.7 & 14.6 \\
\hline Gammaridea & 25.0 & 18.0 & 4.6 & 1.5 & 0.7 & 0.5 & 1.5 \\
\hline Mysidacea & 50.8 & 54.6 & 41.9 & 17.1 & 3.8 & 0.9 & 10.3 \\
\hline Chionoecetes opilio & & & 0.0 & 0.2 & 0.8 & 2.7 & 1.1 \\
\hline Other crustaceans & 4.3 & 8.9 & 5.6 & 2.1 & 0.4 & 1.5 & 1.7 \\
\hline MOLLUSCA & 0.1 & 0.5 & 2.5 & 0.7 & 3.7 & 21.5 & 7.3 \\
\hline Bivalvia & 0.1 & 0.3 & 2.2 & 0.6 & 3.3 & 21.3 & 7.0 \\
\hline Other Mollusca & & 0.2 & 0.3 & 0.1 & 0.4 & 0.1 & 0.3 \\
\hline ECHINODERMATA & 0.2 & 3.1 & 2.2 & 2.5 & 9.2 & 24.5 & 10.8 \\
\hline Echinarachnius parma & & 0.0 & 0.6 & 1.2 & 4.9 & 11.2 & 5.2 \\
\hline Ophiuroidea & 0.2 & 1.4 & 1.6 & 1.3 & 4.1 & 13.2 & 5.5 \\
\hline Other echinodermata & & 1.6 & 0.0 & & 0.3 & & 0.1 \\
\hline OTHER INVERTEBRATES & 15.7 & 11.7 & 5.1 & 1.7 & 3.4 & 7.3 & 4.4 \\
\hline Polychaeta & 15.7 & 11.4 & 3.8 & 1.2 & 0.5 & 0.1 & 1.1 \\
\hline Ctenophora & & & 0.0 & 0.3 & 1.7 & 5.8 & 2.2 \\
\hline Anthozoa & & 0.3 & 1.1 & 0.2 & 1.1 & 1.4 & 1.0 \\
\hline Other invertebrates & & 0.1 & 0.2 & 0.0 & 0.2 & 0.0 & 0.1 \\
\hline OTHER & 4.0 & 0.6 & 1.1 & 0.8 & 0.4 & & 0.4 \\
\hline No. indivs. sampled with stomach contents & 82 & 570 & 632 & 467 & 401 & 184 & 2336 \\
\hline
\end{tabular}


TABLE 7. Volume (\%) of the main preys for H. platessoides by length groups in Div. IIb (ICES, 2002-2003).

\begin{tabular}{|c|c|c|c|c|c|}
\hline \multirow[b]{2}{*}{ Preys } & \multicolumn{4}{|c|}{ Size range $(\mathrm{cm})$} & \multirow[b]{2}{*}{ Total } \\
\hline & $10-19$ & $20-29$ & $30-39$ & $40-49$ & \\
\hline PISCES & & 6.1 & 32.6 & & 27.4 \\
\hline Melanogrammus aeglefinus & & & 27.5 & & 22.2 \\
\hline Other Pisces & & 6.1 & 5.1 & & 5.2 \\
\hline CRUSTACEA & & 57.5 & 45.3 & & 47.0 \\
\hline Mysidacea & & 31.5 & 7.3 & & 11.6 \\
\hline Euphausiacea & & 22.6 & 11.3 & & 13.2 \\
\hline Pandalus borealis & & & 17.2 & & 13.9 \\
\hline Other crustaceans & & 3.4 & 9.6 & & 8.3 \\
\hline MOLLUSCA & & 10.2 & 4.2 & 100 & 5.8 \\
\hline Pectinidae & & 10.2 & 4.2 & & 5.2 \\
\hline Other Mollusca & & & & 100 & 0.6 \\
\hline ECHINODERMATA & 100 & 19.5 & 9.9 & & 12.1 \\
\hline Ophiuroidea & 100 & 19.5 & 9.9 & & 12.1 \\
\hline OTHER INVERTEBRATES & & 4.5 & 7.7 & & 7.0 \\
\hline Anthozoa & & 1.5 & & & 0.3 \\
\hline Polychaeta & & & 7.7 & & 6.2 \\
\hline Other invertebrates & & 3.0 & & & 0.6 \\
\hline OTHER & & 2.1 & 0.4 & & 0.7 \\
\hline No. indivs. sampled with stomach contents & 2 & 16 & 18 & 1 & 37 \\
\hline
\end{tabular}

of the energy distribution (Rijnsdorp, 1990) throughout the year could be extrapolated to the vital cycle of the population, where the value of the condition index would represent the threshold of the energy distribution.

Our results showed significant differences in the condition of individuals in the three areas under the effects of sex, season and year. American plaice showed a lower condition in spawning seasons (spring-summer) with a lower seasonal variation in immature individuals. The disadvantage of working with live weight data of specimens is that gonad weight and stomach content weight must be included. Moreover feeding intensity increases after spawning and this offsets the loss of gonad weight. Macroscopic definition of the maturity stage causes some differences in the sampling criteria and in the establishment of the female spawning stage, because they could be in a later maturing stage. However, this kind of interpretation mistake is not so common in males. This is the reason why we find a totally different result - an increase in condition in females during spawning stage and the contrary in males. This makes it impossible to have an exact observation of the variations in condition of adult individuals. Study of condition through eviscerated weight and histologic data of maturity would provide better information of the relationship between these biological issues. An increase of the feeding intensity in spawning males and females was also found when their condition decreases, which also prove the increase observed in the feeding activity after spawning seasons.

On the other hand, some differences can be seen in seasonal behaviour in the different sizes. These differences could be due to the early or late spawning in relation to age and geographical area. This fact has been reported in American plaice and other species. If the spawning was extended throughout the year, the different maturity stages would be overlapped, and this fact would cause low seasonal differences in the mean of $K_{r}$.

Morgan (MS 2003) examined the spatial and temporal condition of American plaice among Div. 3L, 3N and 30. She found seasonal differences with a higher condition in autumn versus spring. She also observed a 
significant annual difference in condition, and no significant correlations between condition and abundance. Our study coincides with these results. Correlation of condition and biomass (in our case) was only significant in Div. 3M, but graphically we do note a relation, and we also found a parallel between annual feeding intensity and condition. This latest relation was different for spawning individuals: increase in the feeding intensity appeared when condition decreased.

Differences in the feeding intensity and diet composition of American plaice were found by area and the diet also varied in relation with size, which coincides with previous studies (González Iglesias et al., MS 2003). Furthermore, in our study, the differences in the feeding intensity and composition of prey would also have been caused by the different period of sampling in each area and the consequent seasonal and geographical availability of prey. The energy equivalents show significant differences among major prey taxa with seasonal and geographic differences for some species, related to gonadal development and size range of prey. In general, Pisces and Crustacea have more energy density than other prey groups (Steimle Jr. and Terranova, 1985; Lawson et al., 1998). These groups of greater energy density were the major components in the American plaice diet in Div. 3LNO and IIb, while Echinodermata predominated in Div. 3M, a component of lower energy equivalents, offset, in some way, by a greater feeding intensity. Our results showed that in Div. 3M from 1999, the feeding intensity decreased and coincide with a remarkable decrease in predation on Echinodermata and the increase of predation on crustaceans. However these issues are not reflected in a clear difference of condition among areas, taking into account that we are dealing with data from feeding studies carried out in different seasons (spring in $3 \mathrm{LNO}$, summer in $3 \mathrm{M}$ and autumn in IIb).

In these studies there are other aspects which affects to condition, feeding intensity, diet and maturity that should be considered, such as the observed seasonal distribution across depth/temperature (Morgan and Brodie, 1991) or the spawning migrations (Milinsky, 1944; Albert et al., 1994), in order to avoid a slanted sampling of the population and to avoid distorting the results. Another aspect that would help in the study of the condition could be its analysis, taking into account the eviscerated weight altogether with the data of the gonadal histologic study.

\section{Acknowledgements}

This work was possible with the support of the agreement between the Spanish General Secretariat of Maritime Fishing (Secretaría General de Pesca Marítima
- SGPM) and the Spanish Institute of Oceanography (Instituto Español de Oceanografía - IEO). The authors would like to thank the scientific observers on board of commercial fishing vessels and participant staff in the survey, especially Paz Díaz Conde for the help in the preparation of the data.

\section{References}

ALBERT, O. T., N. MOKEEVA, and K. SUNNANA. 1994. Long rough dab (Hippoglossoides platessoides) of the Barents Sea and Svalbard Area: ecology and resource evaluation. ICES C.M. Doc., No. 1994/O:8: 40 p.

ALPOIM, R., and A. ÁVILA DE MELO. MS 2004. An Assessment of American plaice (Hippoglossoides platessoides) in NAFO Division 3M. NAFO SCR Doc., No. 50, Serial No. N5003, 28 p.

ANON. 2004. Report of Scientific Council Meeting, 3-17 June 2004. NAFO Sci. Coun. Rep., 2004, 298 p.

CASAS, J. M. MS 2004. Results from bottom trawl survey on Flemish Cap of July 2003. NAFO SCR Doc., No. 21, Serial No. N4969, 36 p.

COSTOPOULOS, C. G., and M. FONDS. 1989. Proximate body composition and energy content of plaice (Pleuronectes platessa) in relation to the condition factor. Neth. J. Sea Res., 24(1): 45-55.

DURÁN, P., and E. ROMÁN. 2000. Spanish experimental fishings: a cooperative research initiative between scientifics and the local fishing industry. ICES CM 2000/W:03.

DUTIL, J.-D., and Y. LAMBERT. 2000. Natural mortality from poor condition in Atlantic cod (Gadus morhua). Can. J. Fish. Aquat. Sci., 57(4): 815-825.

GONZÁLEZ IGLESIAS, C., E. ROMÁN, and X. PAZ. MS 2003. Food and feeding chronology of American plaice (Hippoglossoides platessoides) in the North Atlantic. NAFO SCR Doc., No. 23, Serial No. N4842, 21 p.

GONZÁLEZ TRONCOSO, D., C. GONZÁLEZ, and X. PAZ. MS 2004. American plaice biomass and abundance from the surveys conducted by Spain in the NAFO Regulatory Area of Divisions 3NO, 1995-2003. NAFO SCR Doc., No. 9, Serial No. N4954, 22 p.

HYSLOP, E. J. 1980. Stomach contents analysis a review of methods and their application. J. Fish. Biol., 17: 411429.

JONSON, D. L., P. L. BERRIEN, W. W. MORSE, and J. J. VITALIANO. MS 1999. Essential fish habitat source document: American plaice, Hippoglossoides platessoides, life history and habitat characteristics. NOAA Tech. Memo., No. NMFS-NE-123.

LAMBERT, Y, and J.-D. DUTIL. 1997. Condition and energy reserves of Atlantic cod (Gadus morhua) during the collapse of the Northern Gulf of St. Lawrence stock. Can. J. Fish. Aquat. Sci., 54(10): 2388-2400.

2000. Energetic consequences of reproduction in Atlantic cod (Gadus morhua) in relation to spawning level of somatic energy reserves. Can. J. Fish. Aquat. Sci., 57(4): 815-825.

LAWSON, J. W., A. M. MAGALHÃES, and E. H. MILLER. 1998. Important prey of marine vertebrate predators in the 
Northwest Atlantic: proximate composition and energy density. Mar. Ecol. Prog. Ser., 164: 13-20.

LE CREN, E. D. 1951. The length-weight relationship and seasonal cycle in gonad weight and condition in the perch (Perca fluviatilis). J. Anim. Ecol., 20: 201-219.

MILINSKY, G. I. 1944. On the biology and fisheries of the long rough dab in the Barents Sea. Trudy PINRO, 8: 388-415.

MORGAN, M. J., and W. B. BRODIE. 1991. Seasonal distribution of American plaice on the northern Grand Banks. Mar. Ecol. Progr. Ser., 75: 101-107.

MORGAN, M. J. 2001. Time and location of spawning of American plaice in NAFO Divisions 3LNO. J. Northw. Atl. Fish. Sci., 29: 41-49.

MS 2003. A preliminary examination of variability in condition of American plaice in NAFO Divisions 3LNO. NAFO SCR Doc., No. 11, Serial No. N4817, 14 p.

MURPHY, B. R., D. W. WILLIS, and T. A. SPRINGER. 1991. The relative weight index in fisheries management: status and needs. Fisheries, 16(2): 30-38.

OLASO, I. 1990. Distribución y abundancia del megabentos invertebrado en fondos de la plataforma cantábrica. Bol. Inst. Esp. Oceanogr. Publ. Esp., No. 5, 128 p.

PAZ, X., C. GONZÁLEZ, and E. ROMÁN. 2004. Spanish bottom trawl survey "Fletán Ártico 2003" in the slope of Svalbard area, ICES division IIb. ICES Arctic fish. working group, 2004, Working Doc. 22.

RIJNSDORP, A. D. 1990. The mechanism of energy allocation over reproduction and somatic growth in female North Sea plaice, Pleuronectes platessa L. Neth. J. Sea Res., 25: 279-290.

RODRIGUEZ-MARÍN, E., A. PUNZÓN, J. PAZ, and I. OLASO. MS 1994. Feeding of the most abundant fish species in Flemish Cap in summer 1993. NAFO SCR Doc., No. 35, Serial No. N2403, 33 p.

SABORIDO-REY, F., and A. VÁZQUEZ. MS 2003. Results from bottom trawl survey on Flemish Cap of July 2002. NAFO SCR Doc., No. 42, Serial No. N4860, 41 p.

STEIMLE, F. W., JR and R. J. TERRANOVA. 1985. Energy equivalents of marine organisms from the Continental Shelf of the temperate Northwest Atlantic. J. Northw. Atl. Fish. Sci., 6: 117-124.

WALSH, S. J. 1994. Life history traits and spawning characteristics in populations of long rough dab (American plaice) Hippoglossoides platessoides (Fabricius) in the North Atlantic. Neth. J. of Sea Res., 32(3/4): 241-254.

1996. Life history and ecology of long rough dab Hippoglossoides platessoides (F) in the Barents Sea. J. of Sea Res., 36(3/4): 285-310.

ZAMARRO, M. J. 1992. Comportamiento alimenticio y reproducción de la platija americana (Hippoglossoides platessoides Fabricius 1780) (pisces, pleuronectidae) en el sur del Gran Banco de Terranova. Tesis doctoral. Universidad de Santiago de Compostela, Facultad de Ciencias Biológicas, Departamento de Biología Fundamental. 